\title{
FAKTOR FAKTOR YANG MEMPENGARUHI NILAI PERUSAHAAN
}

\author{
Rika Fitryani, Citra Ramayani, Desi Areva \\ Program Studi Pendidikan Ekonomi STKIP PGRI Sumaterta Barat \\ fitryanirika9@gmail.com
}

\begin{abstract}
ABSTRAK
This study aims to analyze: 1) the effect of profitability on firm value, 2) the effect of capital structure on firm value, 3) the effect of firm size on firm value, 4) the effect of sales growth on firm value, 5) the effect of the current ratio on firm value, 6) the influence of profitability, capital structure, company size, sales growth and current ratio together affect firm value. The results of this study indicate that: profitability has a significant effect on firm value, capital structure has no significant effect on firm value, firm size has a negative effect on firm value, sales growth has no significant effect on firm value, current ratio has a significant effect on firm value in sub-sector companies. food and beverages listed on the Indonesia Stock Exchange (BEI) 2013-2017
\end{abstract}

\section{Keywords: profitability, capital structure, company size, sales growth and currentr ratio}

\section{PENDAHULUAN}

Dengan perkembangan dunia usaha dewasa ini menjadi meningkatnya persaingan antara perusahaan untuk menjaga kelangsungan hidup perusahaan dalam menghadapi persaingan usaha semakin ketat ini, maka dibutuhkan pengamanan dalam mengelola sumber daya yang dilakukan pihak manajemen secara baik.

Secara umum berdirinya suatu perusahaan memiliki tujuan yang jelas, tujuan pertama yaitu mendapatkan keuntungan optimal, kedua yaitu memakmurkan pemilik usaha dan pemilik saham serta yang ketiga yaitu memaksimalkan nilai perusahaan yang tercermin terhadap harga saham. Ketiga tujuan tersebut secara substansial tidak banyak berbeda, hanya saja penekanan yang di capai setiap masing masing perusahaan berbeda antara satu dengan lainnya

Bursa Efek Indonesia (BEI) atau Indonesia Stock Exchange (IDX) merupakan di pasar modal terbesar di Indonesia. Bursa efek indonesia ini 
memilih peran yang sangat penting untuk masyarakat yang ingin berinvestasi. Perusahaan juga merasa tertolong dengan hal tersebut karena pihak perusahaan dengan mudah akan mendapatkan tambahan modal. Sehingga dari setiap perusahaan akan berpacu dalam meningkatkan keuntungan agar pihak investor berminat menanamkan modal di perusahaan. Bursa efek Indonesia terdapat beberapa jenis perusahaan diantaranya bergerak dibidang jasa, perdagangan dan lain-lain. Salah satu industri terbesar adalah manufaktur

Tabel 1. Data nilai perusahaan subsektor makanan dan minuman yang terdaftar di
Makanan dan minuman tidak terlepas dari kehidupan masyarakat sehari-hari. Manusia yang punya sifat tidak pernah puas dengan yang dimiliki, sifat manusia tidak pernah puas tersebut tentu akan membuat barang yang akan di konsumsi semakin meningkat. Karena banyaknya perusahaan-perusahaan yang ingin memenuhi kebutuhan masyarakat maka masing-masing perusahaan berlomba-lomba untuk meningkatkan perusahaannya dengan cara meningkatkan nilai perusahaan.

\section{Bursa efek Indonesia}

\begin{tabular}{|c|c|c|c|c|c|c|}
\hline \multirow{3}{*}{ No } & \multirow{3}{*}{$\begin{array}{c}\text { Nama } \\
\text { Perusahaan }\end{array}$} & \multicolumn{5}{|c|}{ Tahun } \\
\hline & & 2013 & 2014 & 2015 & 2016 & 2017 \\
\hline & & PBV & PBV & PBV & PBV & PBV \\
\hline 1 & CEKA & 0,65 & 0,87 & 0,63 & 0.00 & 0,85 \\
\hline 2 & DLTA & 9,04 & 9,33 & 4,9 & 4,37 & 3,48 \\
\hline 3 & ICBP & 4,65 & 5,26 & 4,79 & 5,61 & 5,11 \\
\hline 4 & MLBI & 2,56 & 48,67 & 22,54 & 47,54 & 27,06 \\
\hline 5 & MYOR & 5,97 & 4,74 & 5,25 & 6,38 & 6,71 \\
\hline 6 & ROTI & 1,33 & 7,76 & 0,39 & 5,97 & 5,39 \\
\hline 7 & SKLT & 0,93 & 1,36 & 1,68 & 1,27 & 2,46 \\
\hline 8 & STTP & 2,94 & 4,8 & 3,02 & 3,82 & 4,26 \\
\hline 9 & INDF & 1,57 & 1,45 & 1,05 & 1,55 & 1,43 \\
\hline 10 & ULTJ & 6,43 & 4,91 & 4,07 & 3,95 & 3,59 \\
\hline \multicolumn{7}{|c|}{ Sumber: www.idx.co.id } \\
\hline
\end{tabular}


Pada tebel di atas dapat di lihat bahwa terjadi fluktuasi nilai perusahaan atau PBV yang di alami perusahaan di setiap tahunnya. Tidak stabilnya nilai perusahaan di sebabkan karena kemungkinan rendahnya minat investor untuk berinvestasi akibat menurunnya kepercayaan padaa perusahaan sehingga menimbulkan menurunnya harga pada saham sehingga berdampak pada penurunan nilai perusahaan. Dari data di atas juga terlihat bahwa banyak perusahaan yang bernilai positif karena PBV > 1. Oleh karena itu penulis tertarik melakukan penelitian di sub sektor makanan minuman. Bukan hanya nilai perusahaan saja akan peneliti lihat disini, peneliti juga ingin mengetahui bagaimana profitabilitas, struktur modal, ukuran perusahaan, pertumbuhan penjualan dan current ratio yang di alami sub sektor makanan dan minuman.

Ada beberapa faktor yang mempengaruhi nilai perusahaan yaitu profitabilitas. Menurut Kasmir
(2011:196) Profitabilitas adalah rasio untuk menilai kemampuan perusahaan dalam mencari laba. Rasio memberikan ukuran tingkat efektivitas manajemen pada perusahaan. Hal ini ditunjukkan dari laba yang diperoleh dari penjualan serta pendapatan investasi sehingga akan mempengaruhi nilai perusahaan.

Selain profitabilitas, struktur modal diduga mempengaruhi nilai perusahaan. Menurut sartono 2010 dalam (Hasania, 2016:135), struktur modal ialah perimbangan jumlah utang jangka pendek bersifat permanen, utang jangka panjang, saham preferen maupun saham biasa. Berbagai macam rasio di struktur modal, namun dalam penelitian ini menggunakan debt to equity (DER). Menurut kasmir 2010 dalam (Hasania, 2016:135) menyatakan "Debt to Equity merupakan rasio yang digunakan untuk menilai utang dan ekuitas. Rasio ini dicari dengan cara membandingkan antara seluruh 
utang lancar dengan seluruh utang ekuitas".

Selain profitabilitas dan struktur modal, ukuran perusahaan di duga mempengaruhi nilai perusahaan. Menurut Suharli 2006 dalam (Hasania, 2016:135) Ukuran perusahaan ialah di lihat pada total aset dimiliki suatu perusahaan agar dapat di gunakan sebagai kegiatan operasi. Jika suatu perusahaan memilki total aset yang besar, maka pihak manajemen leluasa memepergunakan aset di perusahaan tersebut. Dilihat sisi manajemen, kemudahan dalam mengendalikan perusahaan akan menambah nilai perusahaan.

Selain profitabilitas, struktur modan dan ukuran perusahaan, pertumbuhan penjualan di duga mempengaruhi nilai perusahaan. Menurut Pantow et al (2015:969) Pertumbuhan penjualan ialah merupakan bukti suatu perusahaan benar benar tumbuh. Pertumbuhan penjualan banyak digunakan berbagai pihak, baik pemilik perusahaan, investor, kreditor atau pihak lainnya untuk melihat prospek perusahaan. Dilihat penjualan masa lalu, perusahaan bisa mengoptimalkan sumber daya yang ada untuk mengembangkan nilai perusahaan.

Selain profitabilitas, struktur modal, ukuran perusahaan dan pertumbuhan penjualan, current ratio di duga mempengaruhi nilai perusahaan. Menurut Agus dan Martono 2011 dalam (Hasania, 2016:135) Current rasio ialah perbandingan antara aktiva lancar (curent aset) dengan hutang lancar (curent liabilities).

\section{METODE PENELITIAN}

Jenis penelitian yang dilakukan asosiatif adalah penelitian yang bertujuan untuk mengetahui hubungan antara dua variabel atau lebih. Menurut Sugiyono (2011:61) penelitian asosiatif adalah penelitian untuk memberikan uraian mengenai fenomena atau gejala sosial yang di 
teliti dengan mendeskripsikan tentang nilai variabel mandiri, baik satu variabel atau lebih berdasarkan indikator-indikator dari yang diteliti guna untuk mengetahui pengaruh antara dua variabel atau lebih, atau pengaruh antara variabel bebas dan variabel terikat. Penelitian ini bertujuan untuk mengetahui pengaruh profitabilitas, struktur modal, ukuran perusahaan, pertumbuhan penjualan dan current ratio terhadap nilai perusahaan pada perusahaan sub sektor makanan dan minuman yang terdaftar di bursa efek indonesia tahun 2013-2017.

Penelitian ini akan dilakukan pada situs resmi Bursa Efek Indonesia (BEI) sebanyak 10 perusahaan dari tahun 2013-2017. Penelitian ini di laksanakan pada bulan Juli 2020.

Populasi adalah wilayah generalisasi yang terdiri atas : obyek/subyek yang mempunyai kualitas dan karakteristik tertentu yang di tetapkan oleh peneliti untuk di pelajari dan kemudian di tarik kesimpulannya

Sugiyono

(2013:115). Sedangkan Arikunto (2014:173) mengemukakan populasi adalah keseluruhan subjek penelitian.

Adapun teknik pengambilan sampel yang di lakukan dalam penelitian adalah teknik purposive sampling. Purposive sampling adalah teknik penentuan sampel dengan pertimbangan tertentu, Sugiyono (2013:124) Pengambilan sampel (purposive sampling) di lakukan dengan mengambil sampel dari populasi berdasarkan kriteria tertentu.

Kriteria dalam pengaruh suatu variabel ini yaitu jika $F$ hitung $>F$ tabel maka $\mathrm{H}_{\mathrm{o}}$ ditolak $\mathrm{H}_{\mathrm{a}}$ di terima instrumen dinyatakan signifikan. Jika $\mathrm{F}$ hitung $<\mathrm{F}$ tabel maka $\mathrm{H}_{\mathrm{o}}$ diterima dan $\mathrm{H}_{\mathrm{a}}$ ditolak instrumen dikatakan tidak signifikan.

Menurut Ghozali (2011:98) suatu alat ukur pada dasarnya menunjukkan apakah semua variabel independen atau bebas yang dimasukkan dalam model mempunyai pengaruh secara 
bersama-sama terhadap variabel dependen. Dengan nilai Alpha Cronbach > 0,05. Teknik analisis data yang digunakan yaitu teknik dokumentasi dengan bantuan program Eviews versi 8.

HASIL DAN PEMBAHASAN
Menurut (Ansofino, 2016:147) Fixed Effect adalah mengestimasi data panel dengan menggunakan variabel dummy untuk menangkap adanya perbedaan intersep.

Adapun hasil uji regresi linear berganda dengan menggunakan bantuan program Eviews 8 adalah sebagai berikut:

Tabel 2. Hasil pengujian fixed effect model

\begin{tabular}{crrrr}
\hline Variable & Coefficient & Std. Error & t-Statistic & Prob. \\
\hline \hline C & -1.188009 & 0.550237 & -2.159086 & 0.0363 \\
PROF? & 0.524840 & 0.068121 & 7.704479 & 0.0000 \\
SM? & 0.022208 & 0.145666 & 0.152460 & 0.8795 \\
SIZE? & -0.014447 & 0.031252 & -0.462277 & 0.6462 \\
GRW? & 0.000336 & 0.001111 & 0.302455 & 0.7637 \\
CR? & 0.254205 & 0.076950 & 3.303519 & 0.0019 \\
\hline
\end{tabular}

Sumber: Hasil Olahan Data Sekunder 2020

Model persamaan regresi linear berganda yang dapat dituliskan dari hasil tersebut adalah sebagai berikut:

$$
\begin{aligned}
& Y=a-b_{1} x_{1}-b_{2} x_{2}-b_{3} x_{3}- \\
& b_{4} x_{4}-b_{5} x_{5} \\
& Y=-1,188009+0,524840+ \\
& 0,022208-0,014447+ \\
& 0,000336+0,254205
\end{aligned}
$$

1. Pengaruh profitabilitas terhadap nilai perusahaan pada perusahaan sub sektor makanan dan minuman yang terdaftar di Bursa Efek Indonesia (BEI) tahun 2013-2017
Berdasarkan hasil data tabel dapat dilihat bahwa profitabilitas memiliki nilai koefisiensi bernilai positif 0.52484. Nilai t-statistik sebesar $7.704479>$ t-tabel sebesar adalah 2.01537 dan nilai probabilitas $0.0000<0,05$ artinya profitabilitas berdampak positif dan signifikan terhadap nilai perusahaan pada perusahaan sub sektor makanan dan minuman yang terdaftar di BEI 255 Rika Fitryani, Citra Ramayani, Desi Areva 1/ JHP, Vol. 1 No. 2, 2021 
periode 2013-2017. Dengan demikian $\mathrm{H}_{0}$ ditolak $\mathrm{H}_{\mathrm{a}}$ diterima.

Penelitian ini sejalan dengan hasil penelitian yang dilakukan dalam (Hasania, 2016:142) menunjukan bahwa profitabilitas berpengaruh signifikan terhadap nilai perusahaan. Jadi jika suatu perusahaan memiliki nilai profitabilitas tinggi maka perusahaan tersebut juga akan meningkatkan laba suatu perusahaan, laba yang tinggi juga akan meningkatkan laba suatu perusahaan, laba yang tinggi juga akan menimbulkan nilai suatu saham juga tinggi. Tingginya harga saham perusahaan akan berpengaruh terhadap nilai perusahaan. Nilai perusahaan yang tinggi akan menarik investor untuk menanamkan sahamnya pada perusahaan tersebut.

Hasil penelitian ini sesuai dengan penelitian terdahulu oleh Ayu sri mahatma dewi, Ary wirajaya pada tahun 2013 yang berjudul Pengaruh struktur modal, profitabilitas dan ukuran perusahaan pada nilai perusahaan. Dengan hasil penelitian terdapat pengaruh profitabilitas terhadap nilai perusahaan

2. Pengaruh struktur modal terhadap nilai perusahaan pada perusahaan sub sektor makanan dan minuman yang terdaftar di Bursa Efek Indonesia (BEI) tahun 2013-2017

Berdasarkan hasil data tabel dapat dilihat bahwa struktur modal memiliki nilai koefisieni bernilai positif 0.022208. Nilai t-statistik sebesar $0.15246<\mathrm{t}$-tabel sebesar 2.01537 dan nilai probabilitas $0.8795>0,05$ artinya struktur modal tidak berdampak signifikan terhadap nilai perusahaan pada perusahaan sub sektor makanan dan minuman yang terdaftar di BEI periode 2013-2017.

Penelitian ini sejalan dengan hasil penelitian yang dilakukan dalam (Ignatius, 2017:463) tidak signifikan terhadap nilai perusahaan. Hal ini berarti perusahaanperusahaan perbankan menggunakan modal yang terdiri atas hutang sedangkan diketahui bahwa penggunaan hutang yang tinggi akan menyebabkan timbulnya biaya kebangkrutan dan beban bunga yang 
semakin besar. Apabila biaya kebangkrutan semakin besar, maka biaya modal hutang akan semakin tinggi karena pemberi pinjaman akan membebankan bunga. Akan tetapi hal tersebut terkadang tidak dikuatirkan oleh perusahaan karena apabila manfaat hutang masih lebih besar dibandingkan dengan biaya kebangkrutan maka perusahaan akan terus menggunakan hutang

3. Pengaruh ukuran perusahaan terhadap nilai perusahaan pada perusahaan sub sektor makanan dan minuman yang terdaftar di Bursa Efek Indonesia (BEI) tahun 2013-2017

Berdasarkan hasil data tabel dapat dilihat bahwa ukuran perusahaan memiliki nilai koefisiensi bernilai negatif -0.045748 . Nilai tstatistik sebesar $-0.46228<\mathrm{t}$-tabel 2.01537 dan nilai probabilitas sebesar $0.6462>0,05$ artinya ukuran perusahaan tidak berdampak signifikan terhadap nilai perusahaan pada perusahaan sub sektor makanan dan minuman yang terdaftar di BEI periode 2013-2017. Dengan demikian $\mathrm{H}_{0}$ diterima dan $\mathrm{H}_{\mathrm{a}}$ ditolak.
Hasil penelitian menunjukkan bahwa Ukuran Perusahaan tidak signifikan terhadap Nilai Perusahaan, yang berarti penurunan nilai Ukuran Perusahaan tidak berpengaruh secara signifikan terhadap peningkatan nilai perusahaan

Penelitian ini sejalan dengan hasil penelitian yang dilakukan Regina Rumondor 2015 dalam (Hasania, 2016:135) yang menyatakan bahwa ukuran perusahaan tidak berpengaruh signifikan terhadap nilai perusahaan. Hal ini menunjukkan bahwa besar kecilnya perusahaan tidak akan berpengaruh dengan besar kecilnya nilai perusahaan.

4. Pengaruh pertumbuhan penjualan terhadap nilai perusahaan pada perusahaan sub sektor makanan dan minuman yang terdaftar di Bursa Efek Indonesia (BEI) tahun 2013-2017

Berdasarkan hasil data tabel dapat dilihat bahwa pertumbuhan penjualan memiliki nilai koefisiensi bernilai positif 0.000336 . Nilai $t-$ statistik sebesar $0.302455<\mathrm{t}$-tabel 
sebesar adalah 2.01537 dan nilai probabilitas $0.7637>0,05$ artinya pertumbuhan penjualan tidak berdampak signifikan terhadap nilai perusahaan pada perusahaan sub sektor makanan dan minuman yang terdaftar di BEI periode 2013-2017. Dengan demikian $\mathrm{H}_{0}$ diterima $\mathrm{H}_{\mathrm{a}}$ ditolak.

Penelitian ini sejalan dengan hasil penelitian yang dilakukan oleh Mandalika, (2016:209) menyatakan bahwa pertumbuhan penjualan tidak memiliki hubungan yang signifikan dengan nilai perusahaan. Penjualan perusahaan dari tahun sebelumnya, tidak dapat mengoptimalkan sumber dayanya dan kenaikan pertumbuhan penjualan tidak menaikkan nilai perusahaan, Karena pertumbuhan penjualan memiliki peranan yang sangat penting dalam manajemen modal kerja. Dengan hal itu perusahaan dapat mengetahui seberapa besar pertumbuhan penjualan, perusahaan dapat memprediksi seberapa besar profit yang di dapatkan.
Hasil penelitian ini sesuai dengan penelitian terdahulu oleh Isabella permata dhani, A.A gde setia utama pada tahun 2017 yang berjudul Pengaruh pertumbuhan perusahaan, struktur modal, profitabilitas pada nilai perusahaan. Dengan hasil penelitian terdapat pengaruh pertumbuhan perusahaan secara positif namun tidak signifikan terhadap nilai perusahaan.

5. Pengaruh current ratio terhadap nilai perusahaan pada perusahaan sub sektor makanan dan minuman yang terdaftar di Bursa Efek Indonesia (BEI) tahun 2013-2017

Berdasarkan hasil data tabel dapat dilihat bahwa pertumbuhan penjualan memiliki nilai koefisiensi bernilai positif 0.000336 . Nilai tstatistik sebesar $0.302455<\mathrm{t}$-tabel sebesar adalah 2.01537 dan nilai probabilitas $0.7637>0,05$ artinya pertumbuhan penjualan tidak berdampak signifikan terhadap nilai perusahaan pada perusahaan sub sektor makanan dan minuman yang terdaftar di BEI periode 2013-2017. 
Dengan demikian $\mathrm{H}_{0}$ diterima $\mathrm{H}_{\mathrm{a}}$ ditolak.

Penelitian ini sejalan dengan hasil penelitian yang dilakukan oleh Mandalika, (2016:209) menyatakan bahwa pertumbuhan penjualan tidak memiliki hubungan yang signifikan dengan nilai perusahaan. Penjualan perusahaan dari tahun sebelumnya, tidak dapat mengoptimalkan sumber dayanya dan kenaikan pertumbuhan penjualan tidak menaikkan nilai perusahaan, Karena pertumbuhan penjualan memiliki peranan yang sangat penting dalam manajemen modal kerja. Dengan hal itu perusahaan dapat mengetahui seberapa besar pertumbuhan penjualan, perusahaan dapat memprediksi seberapa besar profit yang di dapatkan.

Hasil penelitian ini sesuai dengan penelitian terdahulu oleh Zuhria hasania, Sri murni, Yunita mandagie pada tahun 2016 yang berjudul Pengaruh current ratio struktur modal, profitabilitas dan ukuran perusahaan pada nilai perusahaan farmasi yang terdaftar di BEI periode 2011-2014. Dengan hasil penelitian terdapat pengaruh current ratio terhadap nilai perusahaan.

\section{KESIMPULAN}

Berdasarkan kepada permasalahan dan pertanyaan penelitian dan pembahasan yang telah dilakukan, maka dapat disimpulkan sebagai berikut:

1. Profitabilitas berpengaruh signifikan terhadai nilai perusahaan. Dengan Nilai konstanta sebesar $\quad-1.188009$ berarti tanpa adanya dampak dari variabel bebas maka nilai variabel terikat nilainya hanya sebesar 1.188009. Hal ini berarti bahwa apabila variabel bebas nilainya nol (profitabilitas, struktur modal, ukuran perusahaan pertumbuhan penjualan dan current ratio ) maka nilai pada variabel nilai perusahaan sebesar -1.188009 . Dengan asumsi variabel lain tidak mengalami perubahan atau nol. 
2. Struktur modal tidak berpengaruh signifikan terhadai nilai perusahaan. Dengan Koefisien regresi variabel profitabilitas $\left(\mathrm{X}_{1}\right)$ sebesar 0.52484 yang bertanda positif. Hal ini berarti adanya dampak positif profitabilitas terhadap nilai perusahaan. Artinya apabila nilai profitabilitas meningkat satu satuan maka nilai suatu perusahaan juga akan meningkat sebesar 0.52484 . Dengan asumsi variabel lain tidak mengalami perubahan atau konstan.

3. Ukuran perusahaan tidak berpengaruh signifikan terhadai nilai perusahaan. Dengan Koefisien regresi variabel struktur modal $\left(\mathrm{X}_{2}\right)$ sebesar 0.022208 yang bertanda positif namun tidak signifikan. Hal ini berarti tidak adanya dampak struktur modal terhadap nilai perusahaan. Artinya apabila nilai variabel struktur modal meningkat atau menurun maka akan meningkatkan atau menurunkan nilai perusahaan
4. Pertumbuhan penjualan tidak berpengaruh signifikan terhadai nilai perusahaan. Dengan Koefisien regresi ukuran perusahaan $\left(\mathrm{X}_{3}\right)$ sebesar 0.014447 yang bertanda negatif dan tidak signifikan. Hal ini berarti tidak adanya dampak ukuran perusahaan terhadap nilai perusahaan. Artinya apabila nilai variabel ukuran perusahaan meningkat atau menurun maka akan meningkatkan atau menurunkan nilai perusahaan.

5. Current ratio berpengaruh signifikan terhadai nilai perusahaan. Dengan Koefisien regresi variabel pertumbuhan penjualan $\left(\mathrm{X}_{4}\right)$ sebesar 0.000336 yang bertanda positif namun tidak signifikan . Hal ini berarti tidak adanya dampak pertumbuhan penjualan terhadap nilai perusahaan. Artinya apabila nilai variabel pertumbuhan penjualan meningkat atau menurun maka akan meningkatkan atau menurunkan nilai perusahaan. 
6. Profitabilitas, struktur modal, ukuran perusahaan, pertumbuhan penjualan dan current ratio secara bersama sama berpengaruh signifikan terhadap nilai perusahaan. Dengan Koefisien regresi variabel current ratio $\left(\mathrm{X}_{5}\right)$ sebesar 0.254205 yang bertanda positif. Hal ini berarti adanya dampak positif current ratio terhadap nilai perusahaan. Artinya apabila nilai variabel current ratio meningkat sebesar satu satuan maka akan menurunkan nilai perusahaan sebesar 0.254205 . Dengan asumsi variabel lain tidak mengalami perubahan atau konstan.

\section{DAFTAR PUSTAKA}

Ansofino, D. (2016). Buku Ajar Ekonomitrika (1st Ed.). Deepublish.

Andri Mandalika. 2016. Pengaruh struktur aktiva, struktur modal dan pertumbuhan penjualan terhadap nilai perusahaan pada perusahaan publik yang terdaftar di BEI (studi pada sektor otomotif) Jurnal berkala ilmiah. Vol 16 no 01
Pantow et al. 2015. Analisis pertumbuhan penjualan, ukuran perusahaan, return on asset dan struktur modal terhadap nilai perusahaan yang tercatat di indeks $L Q 45$. Jurnal $E M B A$. Vol 3. No 1. Hal 961971. ISSN 2303-1174

Arikunto,

S. (2014). Prosedurpenelitian Suatu Pendekatan Praktik. Bandung: Rineka Cipta.

Ghozali, I. (2011). Aplikasi Analisis Multivariate Dengan Program Ibm Spss $20 \quad$ (P. 52,47,48,19160139,59,97,136,1 05,98,205). Badan Penerbit Universitas Diponegoro.

Hasania, Z. (2016). Pengaruh Current Ratio, Ukuran Perusahaan Struktur Modal, Dan Roe Terhadap Nilai Perusahaan Farmasi Yang Terdaftar Di Bursa Efek Indonesia Periode 2011 - 2014. Jurnal Berkala Ilmiah Efisiensi, 16(No 3), 133-144.

Kasmir. (2011). Analisis Laporan Keuangan. Jakarta: Pt Raja Grafindo Persada.

Sri, Ayu, Mahatma Dewi, And Ary Wirajaya. (2013). Pengaruh Struktur Modal, Profitabilitas Dan Ukuran Perusahaan Pada Nilai Perusahaan. Jurnal Akuntansi Universitas Udayana 42: 2302-8556. 
Sugiyono. (2013a). Metode

Penelitian Bisnis. Alfabeta. 